World Lumen Congress 2021 | May 26-30, 2021 |

Iasi, Romania

\title{
The Contribution of Innovative Changes to the Strategic Development of Universities in the Context of Achieving Sustainability
}

\author{
Alina SUSLENCO
}

https://doi.org/10.18662/wlc2021/61

How to cite: Suslenco, A. (2021). The Contribution of Innovative Changes to the Strategic Development of Universities in the Context of Achieving Sustainability. In A. Sandu (vol. ed.), Lumen Proceedings: Vol. 17 World Lumen Congress 2021 (pp. 611-629). Iasi, Romania: LUMEN Publishing House. https://doi.org/10.18662/wlc2021/61 


\title{
The Contribution of Innovative Changes to the Strategic Development of Universities in the Context of Achieving Sustainability
}

\author{
Alina SUSLENCO ${ }^{1}$
}

\begin{abstract}
This paper constitutes a scientific approach, where there have been highlighted the most important innovative changes that influence the development of a bigher education institution and shape the activity of universities towards permanent adaptation to achieve their sustainability. The topicality of the research topic stems from the need to identify effective measures to achieve sustainability in higher education institutions. The aim of the research is to identify the innovative changes that have a positive impact on the strategic development of the universities. The problem of the research lies in highlighting the most important innovative changes that can affect the universities in achieving their sustainability. In this context, we can reiterate that innovative changes have been defined and analysed from the perspective of the need of university change in the direction of their assimilation within institutions. In addition, the innovative potential of the Republic of Moldova was evaluated from the perspective of the analysis of the categories of scientific researchers, of the research fields, of the expenses undertaken by the state for the development of scientific researches. The research methodology focused on the use of several methods: analysis, synthesis, induction, abduction, deduction, qualitative research through documentation, scientific abstraction. In conclusion, we can reiterate that the Republic of Moldova has a valuable innovation potential, which can lead the country to achieve sustainability. The best solution would be the efficient capitalization of the innovative potential of the country but also its direction towards ensuring an ecological-economic-social balance, in the context of applying a management of university sustainability within bigher education institutions.
\end{abstract}

Keywords: Innovative changes, strategic development, sustainability, universities, lifelong learning, artificial intelligence.

\section{Main text}

Universities constitute true vectors of change in the view of the fact that they capitalize on the human potential, making decisive contributions to increasing the competitiveness of the academic arena. Universities create human skills and values by implanting them in young specialists who advocate the capitalization of the innovative potential towards the development of new teaching methods, new

$1 \mathrm{PhD}$, Associate Professor, Alecu Russo Balti State University, Balti, Republic of Moldova, alina.suslenco@mail.ru 
technologies and forms of learning. In the competitive fight, universities must show special skills and abilities necessary for young specialists, which would facilitate their insertion in the labour market, and, on a general level, the achievement of a successful career.

In this context, universities have to make changes in their activity, in order to conform to the dynamic environment and to show flexibility, competitiveness and sustainability.

One of the changes that universities should introduce on their path towards sustainability is the innovative change, which is undeveloped by the specialists in this field. We believe that innovative changes are extremely necessary in a society of intelligence and competitiveness in the context of implementing university sustainability management.

Therefore, we considered it necessary to carry out this research, which will help us to identify the most important innovative changes that higher education institutions must undertake in order to achieve sustainability.

Exploring the specialized literature, we haven't found many works dedicated to the research of the innovative changes to which the higher education institutions have to adapt. Thus, in this context, the given research helped us to define the concept of "innovative changes" but also to analyse their contribution in the creation of sustainable universities.

This paper constitutes a scientific approach, where there have been highlighted the most important innovative changes that influence the development of a higher education institution and shape the activity of universities towards permanent adaptation to achieve their sustainability.

The topicality of the research topic stems from the need to identify effective measures to achieve sustainability in higher education institutions.

The aim of the research is to identify the innovative changes that have a positive impact on the strategic development of the universities.

\section{The research objectives are:}

O1: studying the definition of innovative changes from the perspective of ensuring university sustainability;

O2: identifying the role of innovation management in higher education institutions;

O3: shaping the optimal solutions in order to ensure sustainability in higher education institutions in the context of the COVID-19 crisis;

O4: evaluating the development of the research-innovation system in the Republic of Moldova in the context of innovation changes.

The problem of the research lies in highlighting the most important innovative changes that can affect the universities in achieving their sustainability.

The research methodology focused on the use of several methods: analysis, synthesis, induction, abduction, deduction, qualitative research through documentation, scientific abstraction. In conclusion, we can reiterate that the 
Republic of Moldova has a valuable innovation potential, which can lead the country to achieve sustainability.

The best solution would be the efficient capitalization of the innovative potential of the country but also its direction towards ensuring an ecologicaleconomic-social balance, in the context of applying a management of university sustainability within higher education institutions.

\section{Contents}

\section{Sustainability of higher education institutions - a necessity of the universities of the future}

In a paper, the authors focused on the fundamental rules of sustainability in higher education. The authors used an empirical model in order to describe the basic needs that are important for maintaining sustainability on campuses. In this paper, the authors analysed four different phases of sustainability in higher education that were developed based on their literature review and the empirical study undertaken.

1. The first phase is the development of the vision of sustainability in higher education institutions;

2. The second phase focuses on identifying the mission and objectives of a sustainable university;

3. The third phase identifies the need to create a Sustainability Committee;

4. The fourth phase identifies the sustainability strategies (Velazquez et al. 2006, p. 12).

Schematically, these four phases of sustainability in higher education are shown in Figure 1.

These four phases present all the elements of sustainability within the higher education institutions. We can identify four elements of sustainability in higher education, such as: education, research, information, partnership.

Implementing sustainability - this element is specific to the campus itself. In Figure 1, we highlighted the phases of sustainability in higher education.

Two fundamental means for all these four elements of sustainability that deserve to be implemented in higher education institutions are illustrated by the sustainability awareness and the use of technology, which contribute to the reduction of environmental problems locally or globally.

According to the results of the survey conducted by the researchers, in order to meet the sustainability initiatives, $40 \%$ of the work done depends on cultural awareness and 25\% depends on the technologies applied (Velazquez et al., 2006, p. 12). 


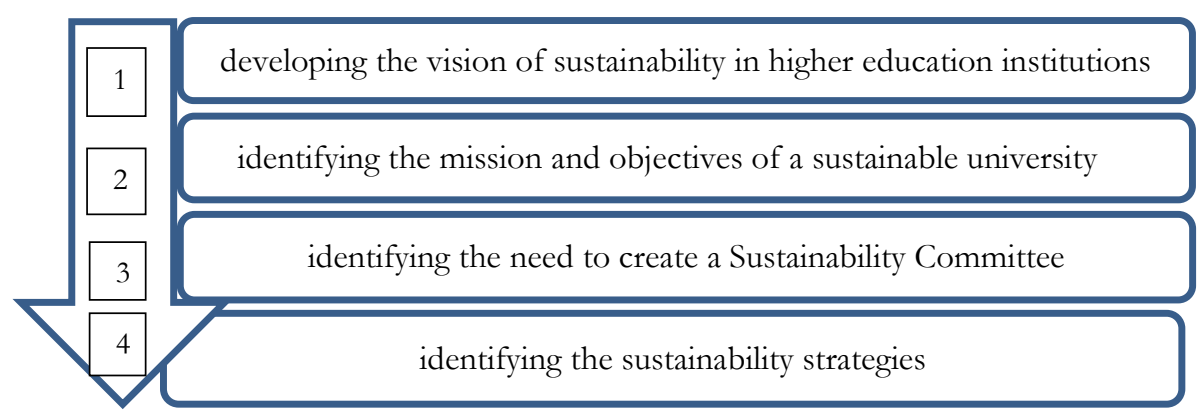

Fig. 1. Phases of sustainability in higher education

Source: elaborated by the author based on Velazquez et al. (2006, p. 12)

In other investigations, the author focused on The Global Reporting Initiative (GRI), which is one of the most important entities in the field of sustainability, focused on the idea of sustainability reporting as a methodology for adopting sustainable practices (Viebahn, 2002, p, 36). Consequently, education, research, policy making and the implementation of sustainability are crucial for ensuring sustainability in higher education institutions (Veibahn, 2002, p. 36; Posner \& Stuart, 2013, p. 6; Richardson \& Lynes, 2007, p. 342).

\section{Sustainable university skills}

In order to achieve sustainability in higher education, institutions in this field must demonstrate several skills that have been outlined in Figure 2.

Availability for higher education has become an issue due to high tuition costs and access to university campuses. More and more students are working and getting enrolled in higher education classes at the same time. Therefore, balancing the courses on campus has become a true challenge. However, the introduction of online education has increased the availability of education on a worldwide scale. The phenomenon of online education expands the target markets and allows the universities to expand their target markets - a key component of sustainability.

Online education may facilitate additional availability of studies for more students. In addition, online education is an example of innovation combined with flexibility - another key component of sustainability. The use of information and communication technology in higher education makes it possible for universities to provide students with more flexible access to learning resources, administrative services and academic staff, but also encourages students to expect such flexibility. 


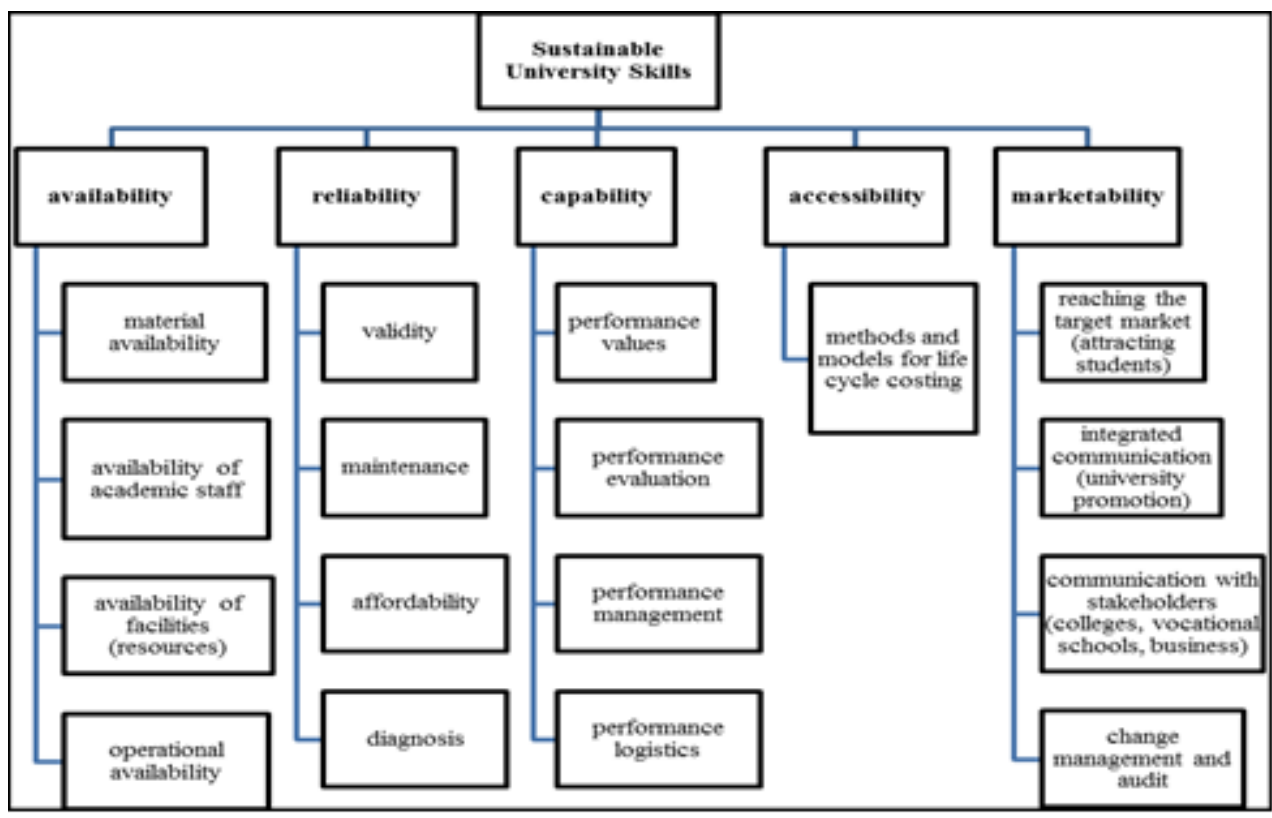

Fig. 2. Skills of a sustainable university

Source: elaborated by the author based on Veibahn (2002, p. 38)

Researcher Ellis explains that reliability refers to the validity, maintainability, affordability and consistency of services. Students must be able to rely on the university that offers the tools for success. The higher education system is supported by the ingenuity and passion of those who have chosen an academic life (Ellis, 2010, p. 75).

Researcher Taylor mentions that universities must ensure that the quality of their services, education and research are properly oriented, so as to train welleducated graduates in the values of sustainability. Teaching and research are intrinsically linked, along with the research support, which constitutes another path to sustainability (Taylor, 2007, p. 176; Salvioni et al., 2017, p. 192; Sardianou \& Genoudi, 2013, p. 3).

According to professor Forrant, "universities can have a transformative and sustaining impact for humane development and can move us toward a more sustainable and people-centred development process" (Forrant \& Pyle, 2002, p. 6). Therefore, for universities to stimulate sustainability, they need to focus on creating new knowledge, preserving indigenous knowledge, disseminating both types of information, economic and social innovation, solving problems associated with rapid globalization and urbanization and developing a strong community-based organization (Forrant \& Pyle, 2002, p. 6). The researcher reiterates that the ability to create sustainability thrives on clearly defining the objectives of the higher education institution and supporting different strategies of researchers and academia. Ongoing research, in the context of ensuring sustainability and research evaluation, is needed for the sustainability strategy and the achievement of the projected objectives. 
Capability refers to values, measures and performance management. A measure of efficiency in a university is represented by the link between the graduate and his/ her career success. In addition, the ability of a university to produce reliable results can be measured by the effectiveness of the institution management. In order to be sustainable, universities must be able to train the students for successful careers. Learning is the basis of a higher level of education. The ability of an institution to train its graduates to solve life problems is crucial for their future success.

A proven way to succeed in the sustainability of a university is to record the employability of graduates of the higher education institution, which not only indicates the ability of a university to provide successful educational services, but also plants its roots for future evolution.

Researcher Hargreaves, on the other hand, mentions that "sustainable leadership matters, spreads and lasts. It is a shared responsibility, that does not unduly deplete human or financial resources, and that cares for and avoids exerting negative damage on the surrounding educational and community environment" (Hargreaves \& Fink, 2006, p. 4). The author reiterates the importance of sustainable management for preserving, protecting and promoting deep and broad learning for everybody, therefore, leadership becomes central to management.

An effective management constitutes one of the fundamental elements of a sustainable higher education institution. Efficient management, i.e., the ability to communicate the objectives of the institution, taking actions wisely to achieve these objectives and communicating the successes of academia and students, while continuously planning new sustainable objectives for the future.

According to professor Ellis, the design of intelligent management can create an ecosystem that adapts to change, improves through learning, learns through experience and can be brought back into balance through the efficiency of the functioning of its own internal processes (Ellis, 2010, p. 75).

Accessibility focuses on the cost life cycle. It is not a secret that universities are registering higher and higher costs, and, in many cases, these are overlooked. As many universities are financially self-sufficient, they are obliged to apply the principles of saving financial resources and adjusting expenditure. A special place belongs to the placement of investments by universities that must focus on identifying sustainable placements, which will help universities to move towards sustainability.

Marketability is defining a market for products or services, understanding consumers' needs, managing change over time, identifying improvements for the benefit of stakeholders, and selling sustainability concepts to those that are resistant to change (Ellis, 2010, p. 75).

\section{Conceptual benchmarks on the role of innovative change in achieving sustainability in higher education institutions}

In our opinion, innovation changes are the category of changes that involve the implementation of new methods, technologies, learning platforms, innovations in higher education in order to increase the competitiveness and sustainability of 
universities based on an innovative culture by involving all members of the academic community.

Innovative changes in universities constitute a stringency in the 21 st century, the century of intelligence, dynamism, technologies, innovations, a century that shapes the activity of higher education institutions and forces them to research, innovate, develop new platforms to increase their competitiveness.

\section{Innovative changes in the university environment:}

- Improving the learning management system - in order to train the students to be competitive on the labour market, and have practical abilities, smart skills, universities need to change their learning management system by focusing on innovative skills formed within universities. The learning management system is not necessarily an example of innovation in higher education, but its implementation in higher education can contribute to new innovations via using technology towards customizing student's navigation from theory to intelligent practical activities. The definition of asynchronous learning helps us understand the need for asynchronous access to this content, especially when this access is not established via a dated university learning management system, more authentic for the student, possibly accessed on their own mobile devices.

- Obtaining new quality certificates - in the higher education system the need for change is vital, especially in the field of quality. Thus, in order to increase the quality of education, to provide quality training, universities must concentrate on implementing new quality standards, aligning with the requirements and, as a result, offering attractive training programs for students focused on training young qualified specialists. Consequently, the accreditation of specialties through the orientation towards sustainability, the opening of new training programs for specialists accredited by the National Attestation and Accreditation Agencies becomes a necessity of the century of change.

- Implementing an open (flexible) curriculum - in order to increase the sustainability of higher education institutions, it is necessary to implement an open curriculum, competitive courses for students, aimed at broadening the horizon of knowledge by focusing on sustainability, global experiences and challenges.

- Competency based learning - is a necessity for higher education institutions that claim to be innovative and want to enhance their image in the national and international arena. The training of skills based on sustainability-oriented learning is a necessity of the 21st century. The training of these skills must be effective, determining the capitalization of the innovation culture of young specialists in higher education institutions and focusing on modelling sustainable skills in an academic environment, taking into account flexibility and innovation.

- Intelligent Data Analysis - is another way to innovate at all levels of education, but higher education institutions could be less prepared for this, due to standardized curricula and assessment practices. Smart data analysis is among the strongest examples of innovation in higher education. 
- "Flexible" faculties - is a necessity to form innovative universities, to safely pave the way for sustainability within higher education institutions. Thus, at the level of faculties, it is necessary to identify the pillars of innovation, to evaluate the innovative potential of the faculty, teachers and students in order to identify effective strategies to be able to infiltrate the change at the level of faculty. Because each faculty has specific goals, it appears as a living organism that needs flexibility and freedom to generate innovation.

- Artificial intelligence is another challenge for competitive universities, a necessity for higher education institutions that want to train competent young specialists, able to meet the demands of the labour market. Critical thinking, causeeffect links, become vectors of the training of competent specialists in higher education institutions.

- Digital textbooks are a necessity for universities that claim to be competitive, for innovative universities that add value to the global experience in terms of sustainability. The ability of teachers to develop interactive teaching materials is becoming a necessity in the 21 st century for competitive universities, the preparation of interactive courses, the development of digital textbooks, increase the visibility of the university and its impact on the vectors of education.

- Video recording of lessons - is an extremely necessary change in order to implement distance learning, and online education. In many of the world's prestigious universities, this practice has already been found to be effective and has proven to be worth implementing. This change induces university confidence, competitiveness and innovative changes in the content of the courses, in the teaching methods applied by university professors.

- New teaching methods - the application of modern, interactive teaching methods, by involving students in practical activities, by stimulating critical thinking, by means of cultivating transdisciplinary thinking, and by means of modern interactive techniques applied in classes and seminars, laboratories. All these factors become vectors of competitiveness in higher education institutions.

- Virtual reality - the application of modern teaching techniques, modern technologies in education changes students' perception of reality, this being seen with different eyes by young specialists.

- Changing sources of income - in the context of financial pressures facing educational institutions, currently, in the context of the Coronavirus epidemic, funding of higher education institutions through state funding, grants and other methods will have to be reduced rapidly - by along with significant cost reductions. This makes "finding new business models for universities" one of the most important innovations. Unlocking the potential of scientific laboratories, accessing international and national projects, attracting investors, opening new innovation centres, become a necessity for sustainable and innovative universities.

- Modern technologies - the application of modern technologies in education is a key to success for higher education institutions because thanks to them universities can become more attractive, competitive, can attract students and train competent 
specialists who will have the opportunity based on skills trained in universities to fit quickly enter the job market and build successful careers.

- Distance learning - is becoming a necessity of the 21 st century, a century in which major changes are taking place in the education sector, in which this sector is becoming vulnerable due to the challenges. Thus, distance learning is a solution for those universities that want to have an attractive educational offer for students and come up with innovative solutions.

\section{Adapting to innovative change - a requirement of competitive universities}

These innovative changes must be implemented in the education sector in the Republic of Moldova in order to increase the competitiveness of higher education institutions in the country, and ensure them a path to sustainability.

The implementation of the "knowledge triangle" - education-research-innovation in the Republic of Moldova is an imperative for the country's development process. Since education has been declared a national priority, it is imperative to strengthen the role of research and development $(\mathrm{R} \& \mathrm{D})$ and develop a strategy on research and development in the Republic of Moldova as a way to increase the productive capital stock and its knowledge, the paradigm of economic development will involve attracting investment, developing exporting industries, promoting the knowledge-based society, including by strengthening research and development, innovation and technology transfer, oriented towards efficiency and competitiveness. In the following, we will outline the aspects of the national research and development strategy until 2020 through Figure 3.

The need for innovation is determined by the need for change. The need for change is due to the depletion of natural resources, global warming, the creation of products that provide humanity with the energy alternative, products that consume and protect the environment, ecological products, products with optimal energy consumption.

The impact of research and development on economic growth is visible in:

a) Impact on productivity.

b) Research and development activities determine an increase in labour productivity by introducing new technologies (products, processes).

c) The impact of a new technology on productivity depends on the complementary investments involved in organizational changes (structure, procedures, management changes).

d) The impact on growth also depends on the level of investment in society in the training of human resources (Suslenco, 2017, p. 142; Suslenco, 2018, p. 189). 


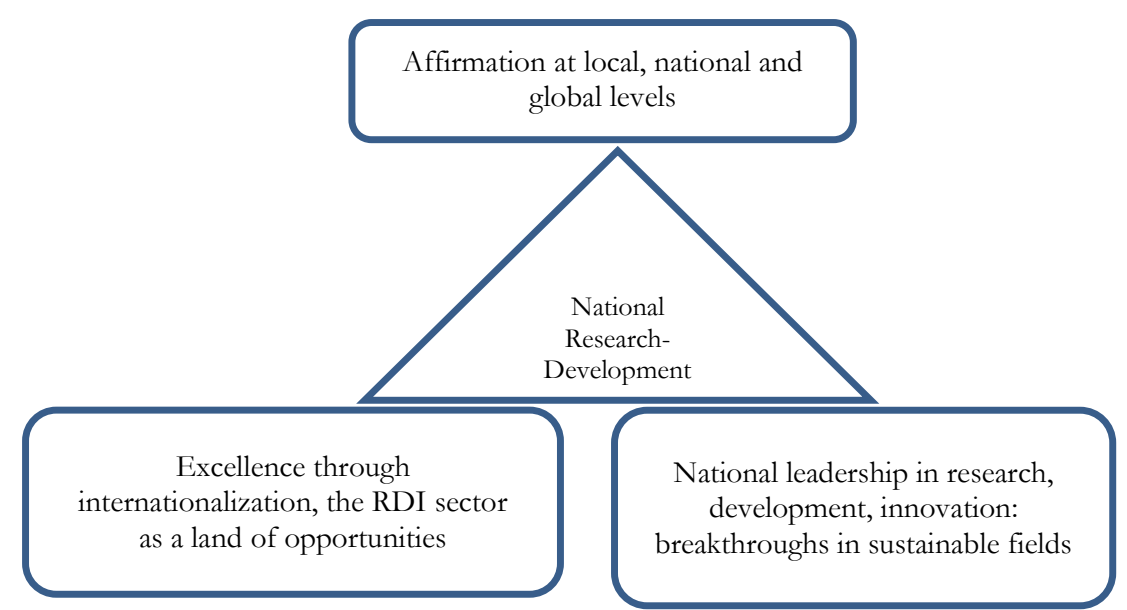

Fig. 3. Aspects of the national research and development strategy until 2020

Source: elaborated by the author (Suslenco, 2017)

Following the analyses, we note that the Republic of Moldova must develop a Program for refurbishment and technological modernization of the country, which sets out (among other things) the dimensions of innovation management:

- innovation strategy;

- organization and culture of innovation;

- the processes of the innovation life cycle (idea management, business model development, process, product/ service), as well as the one of continuous improvement and launch;

- factors favouring the innovation management (human resources management, knowledge management, process management, project management, controlling and IT;

- the results of the innovation, being necessary the systematic evaluation of the results of the innovative activity (AGEPI Innovation Study, 2015).

Higher education institutions in our country must implement innovation strategies that would improve the situation, the competitiveness of these enterprises. The components of a company's innovation strategy are:

- vision: time prospecting of the company, its results, structure and dimensions;

- objectives: the goals that support the achievement of the vision, quantified in the factors: time, investments, quality; the company must determine the strategic directions of the innovative activities and identify the goals in each of them;

- ways to achieve the objectives: diversification, specialization or combination of production, design of new products/ services, processes, penetration of new markets, etc.;

- resources: investment funds, human, material and financial resources;

- deadlines included in the strategy.

By creating such institutions, it is desired:

- broadening the consistency and number of contacts between innovative SMEs - research - innovation - technology transfer - market. 
- establishing the partnership between the intellectual and the industrial property, in the idea of achieving the technological transfer for the benefit of the market.

- identification of innovations, inventions, innovative companies, users of new technologies in order to achieve technology transfer and national or international partnerships.

- dissemination of information and good practices to expand the number of companies accessing Innovation Programs, Structural Funds, FP7/Research for SMEs.

- promoting innovative methods and methodologies, knowledge and technology transfer.

- identifying strategies and solutions for increasing competitiveness through innovation and technology transfer.

- brokerage and matchmaking events to become a pole of discussion, facilitator of partnerships between inventors - research / innovation / technology transfer units - market (AGEPI Innovation Study, 2015).

Thus, we notice that the need to implement such a program is huge for stimulating the competitive environment in our country and for stimulating and cultivating innovative culture in the Republic of Moldova.

\section{Evaluation of the research and development sector in the Republic of Moldova. Major perspectives and challenges in the context of the crisis.}

The dizzying development of the research and development sector has a decisive influence on the country's competitiveness and on the development of the country's potential. That is why the way of developing research and development in the Republic of Moldova must be analysed.

The Research-Development activity in 2019, in the Republic of Moldova took place in 63 institutions, including 40 institutes and research centres, 16 higher education institutions and 7 - other types of units. Out of the total number of units operating in the field of Research-Development, 50 units or 80 percent have the form of state property (NBS, 2020).

As of December 31, 2019, 4058 employees were carrying out their research and development activity in the country, a number 299 people lower than the one registered at the end of 2015 , or $8.8 \%$ lower than in 2018 . The number of women in research-development activity registered $50.2 \%$ of the total number (NBS, 2020).

According to the level of professional training, 1568 persons or $38.6 \%$ of the total employees have doctoral and post-doctoral higher education, 1778 persons $(43.8 \%)$ - bachelor's and master's degree studies, and 277 persons (6.8\%) professional technical studies, 435 people (10.7\%) - have another level of training.

By categories of occupations, the majority of employees in the researchdevelopment activity consisted of researchers -2767 people $(68.2 \%$ of the total), followed by auxiliary staff $(25 \%)$ and technicians (6.8\%). Compared to 2015, there were differences in all categories of occupations: an increase of 0.9 percentage 
points for researchers and technicians and a decrease of 1.4 percent for auxiliary staff and 0.5 percent for other employees (NBS, 2020).

In Table 1. we have schematically shown the dynamics of employees in the research and development activity for the period 2015-2019.

Table 1. Employees in research and development, by categories of occupations, 2015-2019

\begin{tabular}{|c|c|c|c|c|c|c|c|c|c|c|}
\hline & \multicolumn{10}{|c|}{ People } \\
\hline & \multicolumn{2}{|c|}{2015} & \multicolumn{2}{|c|}{2016} & \multicolumn{2}{|c|}{2017} & \multicolumn{2}{|c|}{2018} & \multicolumn{2}{|c|}{2019} \\
\hline & Total & $\begin{array}{c}\text { Wom } \\
\text { en }\end{array}$ & Total & $\begin{array}{c}\text { Wome } \\
n\end{array}$ & Total & $\begin{array}{c}\text { wome } \\
\mathrm{n}\end{array}$ & Total & $\begin{array}{c}\text { Wo } \\
\text { men }\end{array}$ & Total & $\begin{array}{l}\text { Wo } \\
\text { men }\end{array}$ \\
\hline $\begin{array}{l}\text { Employee } \\
\mathrm{s}\end{array}$ & 5033 & 2607 & 4734 & 2419 & 4697 & 2366 & 4451 & 2263 & 4058 & 2037 \\
\hline $\begin{array}{l}\text { Research } \\
\text { es }\end{array}$ & 3368 & 1655 & 3210 & 1577 & 3180 & 1542 & 3054 & 1483 & 2767 & 1315 \\
\hline $\begin{array}{l}\text { Technicia } \\
\text { ns }\end{array}$ & 275 & 183 & 303 & 193 & 311 & 201 & 257 & 167 & 275 & 187 \\
\hline $\begin{array}{l}\text { Auxiliary } \\
\text { personnel }\end{array}$ & 701 & 403 & 594 & 304 & 582 & 296 & 576 & 319 & 510 & 292 \\
\hline Others & 689 & 366 & 627 & 345 & 624 & 327 & 574 & 294 & 506 & 243 \\
\hline
\end{tabular}

Analysing the dynamics of staff in research and development in the Republic of Moldova during the period of 2015-2019, we can see that in this period, the total number of staff in the research and development sector is decreasing from 5033 people employed in this sector in 2015 to 4058 of people in 2019. This negative dynamic is largely fuelled by the dissolution of research institutions, the abandonment of this sector by young people, who want a better paid job and make the choice in favour of other fields than research-development.

At the level of 2019, in the research-development activity, per 100 male researchers there were 101 female researchers, this situation being maintained at the level of the previous year. 2019.

In the figure below, we have shown the distribution of researchers by age in

\section{Researchers' Age, 2019}

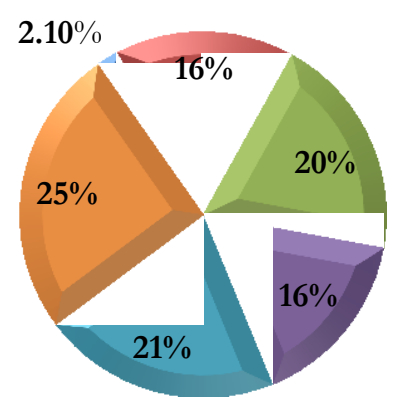

Mup to 25 years

25-34 years

\35-44 years

- $45-54$ years

$\square 55-64$ years

Mover 65 years

Fig. 4. Distribution of researchers by age in 2019

Source: National Bureau of Statistics (2020) 
The distribution of researchers by age groups highlights the fact that the largest share is held by researchers over the age of $65(25.5 \%)$, followed by the age groups 25-34 and 55-64. The lowest share of the total number of researchers in Moldova is in the age group up to 25 years. Thus, this age group holds $2.10 \%$ of all the researchers from Moldova. This indicates that in Moldova the research activity is carried out by experienced people, who know the field and who want to contribute to the development of this field.

In the same context, we can note that the field of research and development in the Republic of Moldova is less attractive for young researchers, which is highlighted by the low share of young researchers in total researchers. This fact is the one that negatively influences the country's innovative development, because this segment of young specialists is one that has an enormous human and intellectual potential that could be developed through the involvement of young specialists in research and development activities, where they could capitalize on their knowledge and skills, contributing to the development of the field and the accumulation of new necessary skills.

In Table 2., we have shown the distribution of researchers from the Republic of Moldova by fields of activity for the period of 2015-2019.

The scientific field in which the largest number of researchers work for the analysed period of 2015-2019 is the natural sciences, where, in the period of 20152019,1165 people or $35.6 \%$ of the total number of researchers were actively involved in 2015, and 1018 people or $36.8 \%$ in 2019.

These sciences are followed by social sciences, engineering and technological sciences where $14.7 \%$ and $14.5 \%$ are active in 2015, while in 2019 in these fields $14.6 \%$ and 14.2 were actively involved.

We must mention that fewer specialists work in the field of humanities $9.5 \%$. The lowest share of women researchers is attested in the field of engineering and technological sciences $-20.6 \%$, and the highest - in the field of social sciences $-58.5 \%$. Compared to 2015, the share of researchers in the field of natural sciences increased by $1 \%$, and those in the field of engineering and technological sciences decreased by $1.9 \%$ (NBS, 2020).

Table 2. Distribution of researchers from the Republic of Moldova by fields of activity for the period of 2015-2019

\begin{tabular}{l|c|c|c|c|c|c|c|c|c|c}
\hline & \multicolumn{10}{|c|}{ People } \\
\cline { 2 - 11 } & $\mathbf{2 0 1 5}$ & \multicolumn{2}{|c|}{$\mathbf{2 0 1 6}$} & \multicolumn{2}{|c|}{$\mathbf{2 0 1 7}$} & \multicolumn{2}{|c|}{$\mathbf{2 0 1 8}$} & \multicolumn{2}{|c|}{$\mathbf{2 0 1 9}$} \\
\cline { 2 - 11 } & Total & $\begin{array}{c}\text { Wome } \\
\mathrm{n}\end{array}$ & Total & $\begin{array}{c}\text { Wom } \\
\text { en }\end{array}$ & Total & $\begin{array}{c}\text { Wome } \\
\mathrm{n}\end{array}$ & Total & Women & Total & $\begin{array}{c}\text { Wo } \\
\text { men }\end{array}$ \\
\hline $\begin{array}{l}\text { Total } \\
\text { Researche } \\
\text { s }\end{array}$ & 3368 & 1655 & 3210 & 1577 & 3180 & 1452 & 3054 & 1483 & $\begin{array}{c}276 \\
7\end{array}$ & $\begin{array}{c}131 \\
5\end{array}$ \\
\hline $\begin{array}{l}\text { Natural } \\
\text { sciences }\end{array}$ & 1165 & 573 & 1142 & 576 & 1117 & 554 & 1083 & 542 & $\begin{array}{c}101 \\
8\end{array}$ & 516 \\
\hline $\begin{array}{l}\text { Engineeri } \\
\text { ng and } \\
\text { technologi } \\
\text { cal } \\
\text { sciences }\end{array}$ & 552 & 160 & 467 & 108 & 466 & 106 & 445 & 103 & 403 & 83 \\
\hline
\end{tabular}


Alina SUSLENCO| Lumen Proceedings 17 | WLC 2021

\begin{tabular}{l|l|l|l|l|l|l|l|l|l|l}
\hline $\begin{array}{l}\text { Medical } \\
\text { sciences }\end{array}$ & 442 & 242 & 414 & 224 & 428 & 240 & 369 & 205 & 339 & 192 \\
\hline $\begin{array}{l}\text { Agricultur } \\
\text { al sciences }\end{array}$ & 411 & 212 & 395 & 205 & 392 & 199 & 392 & 195 & 352 & 169 \\
\hline $\begin{array}{l}\text { Social } \\
\text { sciences }\end{array}$ & 472 & 290 & 471 & 288 & 459 & 280 & 464 & 285 & 393 & 230 \\
\hline $\begin{array}{l}\text { Humanitie } \\
\text { s }\end{array}$ & 326 & 178 & 321 & 176 & 318 & 163 & 301 & 153 & 262 & 125 \\
\hline
\end{tabular}

Source: National Bureau of Statistics (2020)

Subsequently, we intend to focus on the analysis of the distribution of researchers with scientific degrees according to the fields in which they work, during the period of 2015-2019.

Table 3. Dynamics of researchers with scientific degrees by fields of activity, 2015-2019

\begin{tabular}{|c|c|c|c|c|c|c|c|c|c|c|}
\hline & \multicolumn{10}{|c|}{ People } \\
\hline & \multicolumn{2}{|c|}{2015} & \multicolumn{2}{|c|}{2016} & \multicolumn{2}{|c|}{2017} & \multicolumn{2}{|c|}{2018} & \multicolumn{2}{|c|}{2019} \\
\hline & Total & $\begin{array}{c}\text { Wom } \\
\text { en }\end{array}$ & Total & $\begin{array}{c}\text { Wom } \\
\text { en }\end{array}$ & Total & $\begin{array}{c}\text { Wome } \\
n\end{array}$ & Total & $\begin{array}{c}\text { Wome } \\
n\end{array}$ & Total & $\begin{array}{c}\text { Wom } \\
\text { en }\end{array}$ \\
\hline $\begin{array}{l}\text { Total } \\
\text { Researches }\end{array}$ & 387 & 78 & 1327 & 645 & 1692 & 706 & 649 & 710 & 1563 & 656 \\
\hline $\begin{array}{l}\text { Natural } \\
\text { sciences }\end{array}$ & 133 & 22 & 244 & 244 & 633 & 254 & 613 & 510 & 606 & 258 \\
\hline $\begin{array}{l}\text { Engineering } \\
\text { and } \\
\text { technologica } \\
1 \text { sciences }\end{array}$ & 31 & 1 & 27 & 27 & 151 & 25 & 152 & 26 & 152 & 28 \\
\hline $\begin{array}{l}\text { Medical } \\
\text { sciences }\end{array}$ & 86 & 23 & 102 & 102 & 247 & 119 & 219 & 113 & 207 & 100 \\
\hline $\begin{array}{l}\text { Agricultural } \\
\text { sciences }\end{array}$ & 36 & 2 & 44 & 44 & 166 & 44 & 168 & 44 & 160 & 41 \\
\hline $\begin{array}{l}\text { Social } \\
\text { sciences }\end{array}$ & 55 & 18 & 139 & 139 & 281 & 162 & 289 & 168 & 257 & 146 \\
\hline Humanities & 46 & 12 & 89 & 89 & 210 & 102 & 208 & 101 & 181 & 83 \\
\hline
\end{tabular}

If we analyse the structure of researchers in the Republic of Moldova in the fields in which they work in dynamics, then we can highlight the fact that the total number of researchers in 2019 increased compared to 2015 from 387 in 2015 to 1563 in 2019. Thus, there is a substantial increase of 1196 researchers by 2019. This increase was largely explained by the involvement of teachers and researchers in new research projects and the access to new research funding.

In this context, we must highlight the fact that most of the researchers in 2015 were in the fields of "Natural Sciences" with $34.4 \%$ of the total number of researchers and in the field of "Medical Sciences" with $22.2 \%$ of the total number of researchers. These fields are followed by researchers in the fields of "Social Sciences" and "Humanities" that registered in $2015-14.2 \%$ and $11.9 \%$ respectively (NBS, 2020).

If we analyse the structure of researchers in 2019, then we must mention that the largest category of researchers was part of the field of "Natural Sciences" with $38.8 \%$ of all researchers. This field is followed by researchers in "Social Sciences" with 16.4\% and those in "Medical Sciences" with 13.2\%. 
In 2019, "researchers with scientific titles (PhDs, and Full Professors Habilitated Doctors) hold $56.5 \%$ of the total number of researchers. At the same time, in the field of humanities, over two thirds of researchers have scientific degrees, while in the field of engineering and technological sciences - over one third. At the same time, the share of researchers with the scientific title of doctor in the total number of researchers is $44 \%$, and with the scientific title of habilitated doctor $-125 \%$. Women researchers with the scientific title of doctor represent $47.6 \%$ of the total number of researchers with this title, while women researchers with the scientific title of habilitated doctor account for $22.3 \%$. Compared to 2018 , there is a decrease in the number of researchers with the scientific title of doctor with 69 people $(5.4 \%)$ and with the scientific title of habilitated doctor with 17 people (4.7\%)" (NBS, 2020).

In 2015, the expenses for the research-development activities carried out by the units with activity in this field amounted to 451.0 million lei, of which 424.3 million lei, or $94.1 \%$ represent the current expenses and 26.7 million lei the capital expenses or $5.9 \%$ of total expenses. Over $88 \%$ of total expenditures were made in state-owned units.

In Table 4., we show the dynamics of expenditures allocated to the research and development sector for the period of 2015-2019.

Analysing the dynamics of research and development expenditures for the period of 2015-2019, we observe an increasing trend from 451.0 million lei allocated to this sector in 2015 to 498.0 million lei allocated in 2019. Of the total amount allocated most or $88.4 \%$ were allocated in the form of state allowances. In addition, in 2019 most of the expenses, which constitute 484.5 million lei or $97.2 \%$, were allocated for current expenses, and 13.5 million lei or $2.8 \%$ as capital expenses.

Table 4. Dynamics of research and development expenditures during the period of 2015-

\begin{tabular}{|c|c|c|c|c|c|c|c|c|c|c|}
\hline & \multicolumn{2}{|c|}{2015} & \multicolumn{2}{|c|}{2016} & \multicolumn{2}{|c|}{2017} & \multicolumn{2}{|c|}{2018} & \multicolumn{2}{|c|}{2019} \\
\hline & Total & $\begin{array}{l}\text { state } \\
\text { units }\end{array}$ & Total & $\begin{array}{l}\text { state } \\
\text { units }\end{array}$ & Total & $\begin{array}{l}\text { state } \\
\text { units }\end{array}$ & Total & $\begin{array}{l}\text { state } \\
\text { units }\end{array}$ & Total & $\begin{array}{l}\text { state } \\
\text { units }\end{array}$ \\
\hline $\begin{array}{l}\text { Expendit } \\
\text { ures for } \\
\text { research } \\
\text { and } \\
\text { develop } \\
\text { ment, } \\
\text { mil. lei } \\
\end{array}$ & 451,0 & 381,4 & 445,3 & 393,7 & 453,9 & 401,3 & 484,5 & 433,1 & 498,0 & 440,7 \\
\hline $\begin{array}{c}\text { Current } \\
\text { expenses }\end{array}$ & 424,3 & 355,5 & 432,6 & 381,3 & 436,9 & 385,1 & 469,5 & 419,4 & 484,5 & 424,7 \\
\hline $\begin{array}{l}\text { Capital } \\
\text { expendit } \\
\text { ures }\end{array}$ & 26,7 & 25,9 & 12,7 & 12,4 & 17,0 & 16,2 & 15,0 & 13,7 & 13,5 & 12,0 \\
\hline
\end{tabular}

Source: National Bureau of Statistics (2020)

If we analyse the structure of current expenditures in 2019, then we can mention that the largest share has expenditures with staff 363.7 million lei (or $75.1 \%$ ), increasing by 34.1 million lei compared to 2018 At the same time, the other two components of current expenses (materials and other) decreased by 19.1 million lei (NBS, 2020). 
In the figure below we have shown the values of current expenses by components, in the year of 2019.

\section{The values of current expenses by components, in 2019}

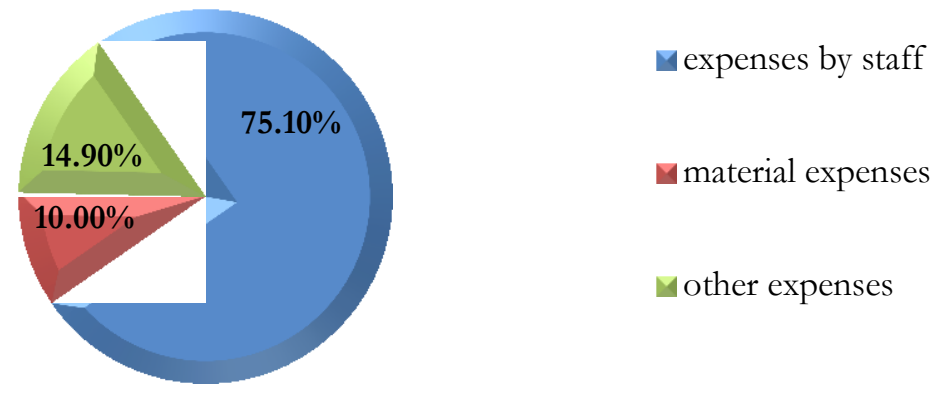

Fig. 4. The values of current expenses by components, in 2019

Source: National Bureau of Statistics, 2020

In 2019, 11.5 million lei were invested in the research-development activity for the endowment with equipment of the units, which carried out researchdevelopment activity (85.2\% of the capital expenditures), with 1.8 million lei more slightly compared to the previous year.

In Table 5., we show the dynamics of current expenditures by main scientific fields in the year of 2016.

Table 5. Dynamics of current expenditures by scientific fields, 2019

\begin{tabular}{|c|c|c|c|c|c|c|c|}
\hline & & \multicolumn{6}{|c|}{ Including scientific fields } \\
\hline & Total & Nat.Sc & Eng. Sc. & Med Sc. & Agricult Sc. & Social Sc & Humanit. \\
\hline $\begin{array}{l}\text { Current } \\
\text { internal } \\
\text { expenditure } \\
\text { on research } \\
\text { and } \\
\text { development } \\
\end{array}$ & 484,5 & 178,8 & 90,0 & 57,5 & 81,2 & 39,2 & 37,8 \\
\hline $\begin{array}{l}\text { Fundamental } \\
\text { research }\end{array}$ & 138,5 & 73,1 & 9,0 & 8,0 & 2,5 & 16,5 & 29,4 \\
\hline $\begin{array}{l}\text { Applied } \\
\text { research }\end{array}$ & 273,4 & 97,0 & 24,1 & 42,5 & 78,7 & 22,7 & 8,4 \\
\hline $\begin{array}{l}\text { Technologic } \\
\text { al } \\
\text { development }\end{array}$ & 72,6 & 8,7 & 56,9 & 7,0 & - & - & - \\
\hline
\end{tabular}

Source: National Bureau of Statistics (2020)

In conclusion, we can mention that the vital wealth of a nation must be protected. Measures must be created, strategies that would ensure opportune conditions for the protection of intellectual property because only in this way will we be able to step on the competitive path. 


\section{Conclusions}

Ensuring competitiveness requires sustainability in documents, acts, rules, activities, concrete actions. This sustainability can be ensured by the protection of the company's intellectual capital. An imperative of ensuring national competitiveness is to ensure an ethical compartment.

In conclusion, we can emphasize that the economic and social development of the last period, has led to the spectacular increase in the number of problems, has created dilemmas between the concept of man-society and the responsibility of the group of managers who ensure the operative leadership of countries, competitive market economy, and, in conditions of globalization, the observance of some ethical and moral norms, the companies being obliged at the same time to respect the cultural diversity, the laws, the customs, the beliefs and the models of behaviour of the society where they carry out their activity.

Ensuring a sustainable development within the universities of the Republic of Moldova, can be ensured by means of:

1. Creating a strategy to ensure sustainable development within the higher education institution - the development and implementation of a strategy on sustainable development in higher education institutions is a necessity of universities that claim to be competitive and must organize a strategic management on ensuring sustainability in higher education institutions. The strategy must focus on implementing effective measures for the sustainable development of the university in the context of the challenges and pressures of the external environment. The strategy must focus on ensuring an ecological, social and economic balance that could ensure the sustainability of the university. In addition, it would be welcome to appoint a commission at the university level, responsible for the implementation of this strategy, which would also be concerned with the implementation of measures to assess the sustainability of the higher education institution.

2. Applying the means of assessing the sustainability of the bigher education institutionin order to achieve sustainability in higher education institutions, periodically, relevant means of assessing the sustainability of the university must be applied, taking into account effective and relevant means. Universities could apply such measures as the sustainability questionnaire, which would help assess the current situation regarding the achievement of the sustainability of the higher education institution.

3. Including the sustainability objectives from the 2030 Agenda of the European Union on sustainable development, in the strategy of sustainable development of the university - is an imperative for higher education institutions in Moldova to identify the goals of sustainable development in the 2030 Agenda of the European Union and to strengthen their activity according to these goals, which will contribute to the sustainable development of the universities.

4. Creating green campuses - this measure derives from the need for universities to create the necessary conditions to ensure sustainable development, which can be 
ensured through the development of green campuses and the creation of those conditions in order to achieve institutional sustainability.

5. Ensuring the university's collaboration with its stakeholders in order to ensure a development focused on sustainability - in order to ensure optimal conditions for achieving sustainability in higher education institutions, it is necessary for the higher education institution to collaborate with its stakeholders, i.e., students, business, its partners, who could help the university to identify optimal conditions for achieving sustainable development.

\section{References}

AGEPI. (2015). Studiu privind imbunătățirea cadrului normativ-legislativ național din domeniul proprietății intelectuale în vederea incurajării activității inovaționale [Study on improving the national normative-legislative framework in the field of intellectual property in order to encourage innovation activity].http://agepi.gov.md/sites/default/files/2015/11/Studiu inovare.pdf

E. U. Council. (2018). Higher education sustainability initiative. https://sustainabledevelopment.un.org/sdinaction/hesi

Ellis, R. (2010). Blended learning in higher education. How students perceive integrations face-to-face and online learning experience in a foreign policy course. Research and Development in Higher Education, 33, (pp.73-81). Australia: Higher Education Research and Development Society of Australasia, Inc.

European Comission. (2017). Strategy EU 2020. https://www.mae.ro/sites/default/files/file/Europa2021/Strategia_Europa_2020. pdf

Forrant, R., \& Pyle, J. L. (2002). Globalization, Universities and Sustainable Human Development, 45(3), 102-106. http://dx.doi.org/10.1057/palgrave.development.1110388

Government of the Republic of Moldova. (2014). Hotarare Nr. 920 din 07.11.2014 cu privire la aprobarea Strategiei de cercetare-dezvoltare a Republicii Moldova pînă în 2020 [ResearchDevelopment Strategy of the Republic of Moldova until 2020] https://idsi.md/files/Strategia_CD_a_RM_2020_cu_Anexe(2).pdf

Government of the Republic of Moldova. (2016). Strategia învățământului superior din Republica Moldova în contextul Procesului Bologna [The Strategy of the Republic of Moldova on higher education]. https://utm.md/edu/legal/strategia rm.pdf

Hargreaves, A., \& Fink, D. (2003). The seven principles of sustainable leadership. Educational leadership: journal of the Department of Supervision and Curriculum Development, N.E. $A, 61(7), 8-13$. http://site.iugaza.edu.ps/magha/files/2014/05/seven principles1.pdf

National Bureau of Statistics. (2021). www.statistica.md

Posner, S., \& Stuart, R. (2013). Understanding and advancing campus sustainability using a systems framework. International Journal of Sustainability in Higher Education, 14(3-4), 5-12. http://dx.doi.org/10.1108/IJSHE-08-2011-0055

Richardson, G., \& Lynes, J. (2007). Institutional motivations and barriers to the construction of green buildings on campus: a case study of the university of Waterloo, Ontario. International Journal of Sustainability in Higher Education, 8(3), 339354. http://dx.doi.org/10.1108/14676370710817183 
Salvioni, D., Franzoni, S. \& Cassano, R. (2017). Sustainability in the Higher Education System: An Opportunity to Improve Quality and Image. Sustainability, 9, 914-921. http://dx.doi.org/10.3390/su9060914

Sardianou, E., \& Genoudi, P. (2013). Which factors influence consumers' willingness to switch to renewable energy sources? Renewable Energy, 57, 1-4. https://doi.org/10.1016/j.renene.2013.01.031

Suslenco, A. (2017). Innovation as a source of competitive advantage of the Republic of Moldova. Economia Contemporană, 1(1), pp.139-149. http://www.revec.ro/images/images site/articole/article d55f618b797b0ac53230 f3c9a1597550.pdf

Suslenco, A. (2018). Valorificarea potențialului inovațional în cadrul instituțiilor de învăţământ superior din Republica Moldova: oportunități şi perspective. Progrese în teoria deciziilor economice în condiții de risc şi incertitudine, XXIX, 183-192. Performantica.

Taylor, E. (2007). An update of transformative learning: A critical review of empirical research (1999-2005). International Journal of Lifelong Education, 26(2), 173-191. https://doi.org/10.1080/02601370701219475

Velazquez, L., Munguia, N. \& Platt, A. (2006). Sustainable university: what can be the matter?. Journal of Cleaner Production, 14, 810-819. https://doi.org/10.1016/j.jclepro.2005.12.008

Viebahn, P. (2002). An environmental management model for universities: from environmental guidelines to staff involvement. Journal of Cleaner Production, 10(1), 312. http://dx.doi.org/10.1016/S0959-6526(01)00017-8 